\title{
Investigating Peer-Assessment in EFL Classes at University Level
}

\section{Zainab Hasan Rasheed}

English Department, College of Education, University of Salahaddin, Erbil, Kurdistan Region, Iraq. E-mail: zeynebhasan92@gmail.com

\section{Fatimah Rashid Hasan Al Bajalani}

English Department, College of Languages, University of Salahaddin, Erbil, Kurdistan Region, Iraq. E-mail: fatimah.hassan@su.edu.krd

\begin{abstract}
:
Peer assessment (PA) is a kind of evaluation which allows the learners to assess their peers' work with the instructions of the teachers and agreed upon criteria. The Ministry of Higher Education and Scientific Research (MHESR) has worked on reforming the higher education system since 2008. It tries to apply the student-centered approach of learning and prepare graduates to be lifelong learners and critical thinkers. One of the alternative methods of assessment in the Student-centered approach is PA. This paper aims to investigate the use of peer assessment in EFL classes at university level. Further, it tries to find out whether peer-assessment is used correctly! Finally, it discovers the challenges encountered by EFL students while implementing PA in the Essay Writing classes. In this study both qualitative and quantitative method are used. The study has conducted in the colleges of Education, Basic Education, and Languages at SUE with the third stage students. The study concludes that peer assessment is used in EFL classes, but it is not used as correct as it should be. The instructors who used it have to illustrate its procedures in the class before using it.
\end{abstract}

Key Words: Peer Assessment (PA), Student-Centered Learning, Observation. 


\section{Introduction:}

One of the alternate methods of assessment in the student-centered approach is Peer Assessment. Although PA is essential, it is either not used or it is used incorrectly. This paper aims at examining the use of PA in EFL classes at the university level and the challenges students face while using PA. The paper also attempts to answer the following research questions:

1. Is peer-assessment implemented in EFL classes?

2. Is peer assessment used correctly?

3. Is peer assessment paid attention to in writing syllabus?

4. Do students face any challenges or difficulties while using peer-assessment?

\section{What is Peer Assessment?}

It is a kind of disposition for students which deals with valuing and qualifying an outcome or the capabilities. Besides, it means learning through supplying detailed feedback and conversing about the evaluations between peers to reach an agreed upon results.

Peers can assess varieties of outcomes, such as writing, oral performances, portfolios, tests, or further qualified actions. Nowadays, learning is obtained by conveying expanded feedback with its logic and examples to the students and making a discussion about other different ideas. Afterwards, the one who is assessed modifies the work through the given opinions during the discussion. This is obviously a kind of formative assessment. At first, peer assessment has to concentrate on the positive sides of the task. For example, this can consider the amount of the mistakes, where the mistakes occurred in, the reason why these are incorrect, and may be some recommendations to correct the mistakes. Next, the peers may talk about uncounted points from the result that could be focused on.

PA started its fame nearly in the end of the last century, and it has been immensely familiar in the last ten years. This kind of assessment can be found in elementary, intermediate schools, universities and also it is seen with trainee teachers who seek for feedback to their works. At the same time, it can be used in the teachers' room when the teachers ask for sharing feedback among themselves (Topping, 2019).

PA as it is cited in (Koc, 2011) by (Van Zundert, Sluijsmensand van Merrienboer, 2010; Strijbos and Sluijsmans, 2010; Falchikov, 2001) is a kind of scoring the tasks by the learners of the same class with suitable guidelines. Furthermore, it is determined as an apparatus for the learners to decide on the tasks of their peers in a qualitative and a quantitative manner, as well as it is a path to persuade the learners for demonstration and collaboration. PA conveys the meaning of implementing critic feedback to different learners' tasks with an agreed upon guideline (Falchikov, 2001) cited in (Koc, 2011).

One of the stages of PA is peer feedback which has a significant effect on learning, if it is performed cautiously. Moreover, it is supportive, it diminishes the errors and it is imperative to enhance the self-controlling abilities (Topping, 2019). PA permits the learners to give and take feedback about their tasks at the minimum amount of time investing by the teacher. Accordingly, PA can be used with varieties of tasks. Normally, learners have a chance to review their tasks before handing them to their teachers for scoring. So, they can revise the given feedback to their tasks and upgrade the 
quality of them as well as they learn from this procedure (Landry et al., 2015). PA may be performed without mentioning the names of the students who assess their peers. To avoid bias, it is recommended to select the students haphazardly.

PA can be summative and formative too. If it is considered as a formal part of the whole assessment process, so it is summative. But it is formative if its purpose is merely to let students give and receive feedback (Race, 2001).

\section{Different views on Peer Assessment :}

One aspect defends PA by identifying it as a chance to engage the learners in getting to know themselves through discussing and explaining the standards, arranging the tasks and judging them, as these are all steps of assessment procedure. Concerning writing, PA allows students to decide on the aim, applicability, features, sentence pattern, consistency of their tasks as well as their peers' works. In this way, associating the learners with PA is qualifying them for their future and supporting them to be lifelong learners (Mutwarasibo, 2016).

Contrarily, some views are in contrast with using PA and they think that it is not trustworthy nor reliable. Mostly, they believe that learners do not have satisfactory skills and they are not enough confident to assess their peers' works, or they do PA with the thought that finally their teacher will judge about their works (Mutwarasibo, 2016).

Lastly, (Topping, 2000) cited in (Mutwarasibo, 2016) states that the benefits and drawbacks which are highlighted by the learners and their teachers are similar to each other. So, it can be claimed that all the views have impact on affirming validity and reliability of PA.

\section{Characteristics of Peer Assessment :}

Keith Topping is one of the pioneers of using peer assessment and he has his own literature about it. He explained the characteristics of peer assessment so deeply in a way that it can be used in every level of studying and with every situation.

As he stated in (Topping, 2019), PA varies according to the classroom atmospheres and the grades of the students as well as the content of the tasks. The only distinction is that whether PA has a summative status or a formative status or both of them in the assessment process of a specific course. Furthermore, PA may be done quantitatively or qualitatively or with both ways, but the qualitative way works better, because it provides a wide range of feedback concerning the approving and improving points about the work. Moreover, he thinks that involving learners in assessment of writing tasks differs from evaluating oral utterances and students have to be able to take responsibilities and to feel satisfied about themselves.

To decide on doing PA with volunteer students or doing it as an obligatory activity, we have to pay attention to the students' anticipations. It is suggested to do this optionally at first; otherwise, learners will be against performing this kind of assessment. Thus, a small number of learner refuse PA, but subsequently they feel comfortable to participate in PA tasks. It is also important to discuss the guidelines and the form of the task with students, because it allows them to make the activity more valid. (Topping, 2019)

One of the most effective features of PA is to identify the kind of the feedback which is shared among the peers. The positive feedback encourages students to do their next tasks more efficiently, and the aim of having negative feedback is 
to determine the points that have to be updated with the appropriate time for learners to refine their works. (Topping, 2019)

Place and time are two crucial features of PA. Topping (2019) attests that PA can take place in both formal and informal places, like class and a park or a garden. Relating to time, learners have to be given a specific time to complete the PA tasks on time. Another feature of PA is that how much the instructors can control the validity and reliability of the task which is performed. Thus, monitoring is an essential issue in PA activities (Topping, 2019).

\section{Designing Peer Assessment:}

PA is engaging learners in assessment. So, it is suggested that students have to estimate their peers' works after finishing a specific course and supply productive feedback (Topping, 2019). However, PA is a kind of activity in which learners have to be instructed and the teachers do not have to expect much knowledge from the learners at the beginning (Sluijsmans, 2002).

To construct a PA task that helps in developing the learners' experience (Sluijsmans, 2002) has presented four steps (Figure.1) of designing PA by (Stiggin, 1987) which identifies the areas to be assessed by the students. 


\section{Peer Assessment Purpose}

This means that students learned how to evaluate a friend and they feel ready to have a duty which allows them to decide on a work critically by using suitable guidelines.

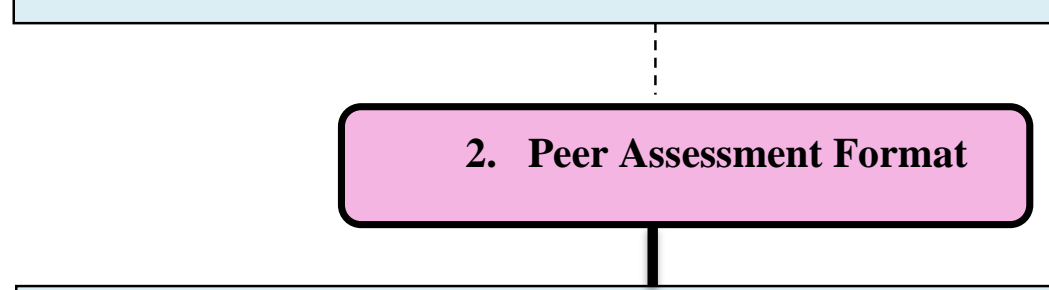

Within peer assessment tasks there are different skills and they have to be worked on distinctively at different times. Prior to work on them as a whole activity.

\section{Peer Assessment Criteria}

Generally, in peer assessment tasks learners will be scored separately. Although, they may grade their peers mistakenly in the areas of accord among themselves and giving a higher score than what is expected, or conspire scoring which makes the grades so close to each other inside one group.

These kinds of forms are constructed by the investigators to inspect the quality of tasks which are performed in peer assessment and their written comments. Research, attendants graded all the peer assessment works in a quantitative way. They designed a grading form with a number of variables, such as: usage of the standards and quality of the comments, whether they are constructive or destructive, and form of the task.

Figure 1: Four Steps of Designing Peer Assessment (Sluijsmans, 2002)

Conclusively, Falchikove and Golfinch (2000) briefed the arrangement of PA studies as the following:

1. Stay away from involving the students in crowded groups.

2. Allow students to score the whole task all at once not many distinct parts. 
3. Prior to applying the criteria, let the students talk about the standards of the criteria.

4. Do not forget that PA can be applied in any subject and with any grade of students.

\section{Challenges of using peer assessment:}

One of the most obvious difficulties in the area of teaching is the factor of time, because the instructors cannot match what they want with the given specific time appropriately.

Topping (2019) stated that at the beginning of using PA, teachers may find it time consuming, but when the students get used to do this and after they learn how to do it, the process will pass gently with the specific given time. Thus, it can be said that PA in this way can satisfy the instructors for saving time.

Assessing and scoring learners' tasks and especially their written works is not such a simple process. For this reason, Liado et al. (2013) stated that this process of evaluation will be so harder for the learners, because they have little information and skill about assessment. So, this may lead to a wrong scoring.

According to what the researchers observed in the Essay Writing classes, students face difficulties while writing comments for their peers. They lack confidence to write feedback on the work of their peers and if they do, they write it in their native language.

It is essential for the instructors to identify "peer"; to whom is this related; who can they call "peer"; are they students from the same level, higher levels or lower levels; do they perform PA for the same topic of for a different one? Generally, peers have to be students and they can be categorized to (close-peer) and (distant-peer). Close-peers are those learners who have the same level of studying, and the learners who have different levels of studying are called distant-peers (Topping, 2019).

\section{Population and Sampling:}

The population of this study is restricted to the $3^{\text {rd }}$ stage EFL students at the Department of English in the College of Education, College of Languages and College of Basic Education/ Salahaddin University-Erbil for the academic year 2018-2019. The total number of the $3^{\text {rd }}$ stage students in the three colleges is 360 male and females, divided to A and B groups in the colleges of Education and Basic Education, and to A, B, C groups in the College of Languages (see Table 1).

The sample of the study consisted of 225 students who were randomly selected and it represents $\% 66.9$ of the population which is 360 students in the three colleges.

Table 1: Population and Sampling

\begin{tabular}{|l|l|l|c|}
\hline College Names & Population & Sample & Percentage \\
\hline College of Education & 90 students & 50 student & $\% 66.9$ \\
\hline College of Basic Education & 114 students & 80 students & $\% 66.9$ \\
\hline College of Languages & 156 students & 95 students & $\% 66.9$ \\
\hline
\end{tabular}




\section{Instruments of the Study:}

\section{The Questionnaire}

In this study, the researchers have used rating scales to obtain clear information from the answers of the participants. Likert scale-which was produced by Rensis Likert in 1932 is the most appropriate scale to be used for the questionnaire. The researchers used a three-point frequency scale from Likert scale, they are "always, sometimes, never" (Brace, 2004). The questionnaire consists of 24 items.

After the validation of the jury members, the tool has to be piloted. The researchers piloted the tool in the College of Education, Salahaddin University-Erbil, before distributing it to all the participants of the study. Piloting should be done at least with 5 to 10 participants (Johnson and Christensen, 2014). The researchers chose a sample of 15 students to pilot the study.

The answers of the respondents have shown no serious problem concerning the language and the items of the questionnaire; the items have suited the learners' understanding level; and the specific time for completing the questionnaire was 45 minutes.

\section{Observation Checklist:}

The second tool of the study is an observation checklist that was prepared by the researchers to collect the qualitative data and a part of the quantitative data of the study. To discover the steps of implementing PA and the problems learners face while doing PA activities, the researchers had to observe the Essay writing classes in the mentioned colleges at Salahaddin University-Erbil. During the observation processes, the researchers were sitting in the back of the class without interacting with students or the teacher until the end of the lecture. This way of observation is one of the shapes in Best and Kahn (2006).

Certainly, what the researchers recorded in these observations strengthens the quantitative data which is collected through the questionnaire.

Concerning this study, the observation process lasted for three months and the researchers attended the classes unobtrusively. They did not face any complains by the students and the teachers of the courses. Moreover, they prepared the observation checklist by categorizing it into four parts (Methods and Syllabus, Steps of Implementing Peer assessment, Challenges facing students and a category named 'others'). Each part has its own related items. As a scale for the checklist the researchers used (Yes/No) responses for the items, to have exact answers.

Concerning the validity and reliability of this checklist, researchers sent it to a number of specialists to check it and give detailed feedback about the items and the construction of the checklist. After the approval of the experts, the researchers had applied the checklist for the observations. Moreover, for checking the consistency of the checklist the researchers observed the classes with one of their colleagues to affirm the reliability of the checklist.

Finally, each research has to follow some ethical issues before starting the study and in some cases during the study's progress. The initial step was taking the permit of the heads of the English Departments in the mentioned colleges. 
After their approval, the researchers contacted the teachers of the Essay Writing courses and took their permissions to observe their classes for a period of time. It is important to mention that the researchers followed all the steps of ethical issues correctly.

\section{Results:}

The results analyzed according to the research questions (RQs):

RQ1: Is peer-assessment implemented in EFL classes?

RQ 2: Is peer assessment used in a correct way?

These two questions are answered through the results of items $3,4,5,6,7,8,10,11$ in the questionnaire.

Table 2: Results Related to RQ 1 and RQ 2

\begin{tabular}{|c|c|c|c|c|c|c|}
\cline { 2 - 7 } Items & \multicolumn{2}{|c|}{ Never } & \multicolumn{2}{c|}{ Sometimes } & \multicolumn{2}{c|}{ Always } \\
\cline { 2 - 7 } & Count & \%percent & Count & \%percent & Count & \%Percent \\
\hline 3 & 24 & 10.7 & 124 & 55.1 & 77 & 34.2 \\
\hline 4 & 16 & 7.1 & 95 & 42.2 & 114 & 50.7 \\
\hline 5 & 29 & 12.9 & 121 & 53.8 & 75 & 33.3 \\
\hline 6 & 33 & 14.7 & 123 & 54.7 & 69 & 30.7 \\
\hline 7 & 56 & 24.9 & 112 & 49.8 & 57 & 25.3 \\
\hline 8 & 36 & 16 & 105 & 46.7 & 84 & 37.3 \\
\hline 10 & 36 & 16 & 114 & 50.7 & 75 & 33.3 \\
\hline 11 & 44 & 19.6 & 121 & 53.8 & 60 & 26.7 \\
\hline
\end{tabular}

According to the results of items 3, 4, 5, 6, 7, 8, 10, and 11 and their percentages $55.1 \%, 50.7 \%, 53.8 \%, 54.7 \%, 49.8 \%$, $46.7 \%, 50.1 \%$, and $53.8 \%$, PA is used in EFL classes to a good extent. To be more specific, the results of items 4, 5, and 8 indicate that PA is used in a correct way depending on the significant difference among the answers of never and always scales. In item 4 , the percentage of never is $\% 7$, meanwhile always is $\% 50.7$; as for the fifth item, never is $\% 12.9$ and always is \%33.3. Concerning item 8 , never is $\% 16$, but always is $\% 37.3$.

In all the tables (count) stand for number of the students who answered and (percent) stands for the percentage. 
Table 3: Results of RQ 1 and RQ 2 regarding the observation checklist

\begin{tabular}{|c|c|c|c|}
\hline Items & Answers & Count & percent \% \\
\hline \multirow{2}{*}{5} & No & 6 & $60.00 \%$ \\
\cline { 2 - 4 } & yes & 4 & $40.00 \%$ \\
\hline \multirow{2}{*}{6} & No & 8 & $80.00 \%$ \\
\cline { 2 - 4 } & yes & 2 & $20.00 \%$ \\
\hline \multirow{2}{*}{7} & No & 8 & $80.00 \%$ \\
\cline { 2 - 4 } & yes & 2 & $20.00 \%$ \\
\hline \multirow{2}{*}{8} & No & 4 & $40.00 \%$ \\
\cline { 2 - 4 } & yes & 6 & $60.00 \%$ \\
\hline \multirow{2}{*}{9} & No & 6 & $60.00 \%$ \\
\cline { 2 - 4 } & yes & 4 & $40.00 \%$ \\
\hline \multirow{2}{*}{10} & No & 8 & $80.00 \%$ \\
\cline { 2 - 4 } & yes & 2 & $20.00 \%$ \\
\hline \multirow{2}{*}{11} & No & 0 & $0.00 \%$ \\
\cline { 2 - 4 } & yes & 10 & $100.00 \%$ \\
\hline \multirow{2}{*}{12} & No & 10 & $0.00 .00 \%$ \\
\cline { 2 - 4 } & yes & 0 & $0.00 \%$ \\
\hline
\end{tabular}

Based on the results shown in Table 3, the results of items 8 and11 of the observation checklist show that PA is used correctly with a percentage of $60 \%$ and $100 \%$ respectively. This indicates that teachers monitor students correctly and students themselves help each other to improve their works. Generally, the results of items 5, 6, 7, 9, 10, and 12 indicate that the majority of teachers do not explain the procedures of PA to their students. Moreover, the teachers do not give strategies of doing PA; they do not provide criteria to be used in PA. The students do not write comments on the work they assess and teachers do not ask students to reflect on their learning.

RQ3: Is Peer Assessment paid attention to in Writing Syllabus?

Table 4: Results Related to RQ 3

\begin{tabular}{|c|c|c|c|c|c|c|}
\cline { 2 - 7 } Items & \multicolumn{2}{|c|}{ Never } & \multicolumn{2}{c|}{ Sometimes } & \multicolumn{2}{c|}{ Always } \\
\cline { 2 - 7 } & Count & \%percent & Count & \%percent & Count & \%percent \\
\hline 1 & 12 & 5.3 & 157 & 69.8 & 56 & 24.9 \\
\hline 2 & 18 & 8 & 128 & 56.9 & 79 & 35.1 \\
\hline 9 & 45 & 20 & 116 & 51.6 & 64 & 28.4 \\
\hline 22 & 25 & 11.1 & 97 & 43.1 & 103 & 45.8 \\
\hline 24 & 40 & 17.8 & 99 & 44 & 86 & 38.2 \\
\hline
\end{tabular}


The students choose sometimes on the scale with a percentage $69.8 \%, 56.9 \%$, and $51.6 \%$ for the items 1,2 , and 9 in the questionnaire respectively. This indicated that the students believe that the setting of writing classes is helpful in using PA. Regarding the results of items 22 and 24, the students chose always on the scale with a percentage $45.8 \%$ and $38.2 \%$ respectively. This also means that the students believe that the writing classes setting helps them in using PA.

Table 5: Results of RQ 3 regarding the Observation Checklist

\begin{tabular}{|c|c|c|c|}
\hline Items & Answers & Count & percent \% \\
\hline \multirow{2}{*}{1} & No & 0 & $0.00 \%$ \\
\cline { 2 - 4 } & Yes & 10 & $100.00 \%$ \\
\hline \multirow{2}{*}{2} & No & 10 & $100.00 \%$ \\
\cline { 2 - 4 } & Yes & 0 & $0.00 \%$ \\
\hline \multirow{2}{*}{3} & No & 0 & $0.00 \%$ \\
\cline { 2 - 4 } & Yes & 10 & $100.00 \%$ \\
\hline \multirow{2}{*}{4} & No & 7 & $70.00 \%$ \\
\cline { 2 - 4 } & Yes & 3 & $30.00 \%$ \\
\hline
\end{tabular}

According to the results of Table 5, items 1 and 2 of the observation checklist show that the learner-centered method is used; this helps students and teachers in using PA in the class. The result of item 3 indicates the use of pair work in class and this facilitate using PA in class. Results of item 4 reveal that PA does not have a formal status in the course since $70 \%$ of the teachers do not mention it in their course books.

RQ4: Do students face any challenges or difficulties while using PA?

Table 6: Results of RQ 4 on the Challenges Students Face while Using PA

\begin{tabular}{|c|c|c|c|c|c|c|}
\cline { 2 - 7 } Items & \multicolumn{2}{|c|}{ Never } & \multicolumn{2}{c|}{ Sometimes } & \multicolumn{2}{c|}{ Always } \\
\cline { 2 - 7 } & Count & \%percent & Count & \%percent & Count & \%Percent \\
\hline 12 & $\mathbf{2 8}$ & $\mathbf{1 2 . 4}$ & $\mathbf{9 4}$ & $\mathbf{4 1 . 8}$ & $\mathbf{1 0 3}$ & $\mathbf{4 5 . 8}$ \\
\hline 13 & $\mathbf{3 9}$ & $\mathbf{1 7 . 3}$ & $\mathbf{1 2 2}$ & $\mathbf{5 4 . 2}$ & $\mathbf{6 4}$ & $\mathbf{2 8 . 4}$ \\
\hline 14 & $\mathbf{8 4}$ & $\mathbf{3 7}$ & $\mathbf{8 2}$ & $\mathbf{3 6 . 8}$ & $\mathbf{5 9}$ & $\mathbf{2 6 . 2}$ \\
\hline 15 & $\mathbf{4 9}$ & $\mathbf{2 1 . 8}$ & $\mathbf{1 2 1}$ & $\mathbf{5 3 . 8}$ & $\mathbf{5 5}$ & $\mathbf{2 4 . 4}$ \\
\hline
\end{tabular}

According to the results of item 12 in the questionnaire, the students find PA as having a lot of responsibility to do it; the percentage of always on the scale is $45.8 \%$, sometimes is $41.8 \%$, and never is $12.4 \%$. This means that the majority of students believe that they need to take a lot of responsibility while doing PA and this is problematic for them. Results of item 13 , i.e., $54.2 \%$ sometimes and $28.4 \%$ always, show that the majority of students find PA needs written comments on the assessed work; this creates a problem to them. 
In item 14 , it is seen that $37 \%$ of students never use their mother tongue in PA while $36.8 \%$ sometimes use their mother tongue and 26.2 always use it. This means that the majority of them have problems in using English to write comments on their peers' work. Meanwhile, results of item 15 show that the majority of students have problems with lack of selfconfidence when using PA since $24.4 \%$ selected always and $53.8 \%$ chose sometimes. On the scales.

Table 7: Results of RQ 4 on the Challenges students face while using PA: The Checklist

\begin{tabular}{|c|c|c|c|}
\hline Items & Answers & Count & percent \% \\
\hline \multirow{2}{*}{13} & No & 10 & $100.00 \%$ \\
\cline { 2 - 4 } & Yes & 0 & $0.00 \%$ \\
\hline \multirow{2}{*}{14} & No & 0 & $0.00 \%$ \\
\cline { 2 - 4 } & Yes & 10 & $100.00 \%$ \\
\hline \multirow{2}{*}{15} & No & 2 & $20.00 \%$ \\
\cline { 2 - 4 } & Yes & 8 & $80.00 \%$ \\
\hline
\end{tabular}

According to the results of item 13, the researchers think that students do not face any difficulty concerning time of the activity and the percentage is $100 \%$. Results of item 14 shows that students mostly use their mother tongue while giving feedback; the $80 \%$ of them lack self-confidence in writing comments in English.

\section{Discussion of the results:}

Nowadays, language classes in general are learner-centered and they are suitable for setting the classes as groups or pairs (Al Bajalani \& Kiani, 2018). This nature of the classes requires engaging students in assessment of their works (see Table 2 and 3). PA is a way to involve students in assessing their works for the sake of learning and it gives students a chance to write comments on the works with special criteria for this kind of assessment. In the writing classes of the previously mentioned colleges, instructors give that chance to the students because they want their students to be qualified assessors in the future and PA helps to remove the burden of teacher assessment.

The process of using PA is an important issue that teachers and students should focus on more deeply. Topping (1998) summarizes this process with a typology since it deals with the skills of learners, the way they improve each other's works, clear explanations of the procedures of PA by the instructors, special strategies for using PA before performing it, criteria to be used in PA, and how the instructor monitor the class while learners are executing PA activities. In Table 4 and Table 5, it is demonstrated that there is a positive thought of implementing peer-assessment but it has to be improved and it needs some regulations. For example, the instructors have to train their students before asking them to perform any PA activities (Topping, 2019; Falchikov \& Goldfinch, 2000). To engage students with the best way of PA, they have to be taught how to peer assess each other; for instance, a sample of PA activity can be displayed for the students with its criteria. Moreover, the criteria used in PA have to be set by the instructors and the students together. In this kind of assessment, teachers' role is like facilitators in the classes just (Hussein \& Al Bajalani, 2018), and they have to provide the students with appropriate strategies for implementing PA. At the same time, they have to monitor them and encourage them to be confident and produce the best of their works. The steps of implementing PA need more improvement 
compared to the roles of the teachers in the class and their guidance to the students (Table 5). The reason behind this distinction in the implementation of PA in the mentioned colleges could be related to some factors such as inability of the learners to perform what is required from them, the time restrictions, or some of the instructors may resist involving them in a complex process like assessment, etc. Teachers may think that they can find many techniques to engage students in learning without involving them in assessment.

Concerning the challenges of using PA, the researchers think that PA is not time consuming as it is claimed by (Topping, 2019; Lladó et al., 2013). It is challenging in the beginning but later the students learn how to perform their task with PA. The observations of the researchers reveal that most of the learners face difficulty while writing comments for their peers, and they lack confidence for giving feedback (see Table 6 and 7).

The results show that the classes do not have a classical style and teachers are not the only director of the class, but they are members of the classes. Regarding the formal status of PA in coursebooks, the results are different. This creates some debatable questions such as Do instructors find PA difficult for their students? Do the students agree with the idea of being assessed by one of his/her friends? Are the writing courses so restricted and time limited? These might be considered as causes of rejecting PA as a formal assessment in the teachers' coursebooks.

Despite the fact that PA can reduce teacher assessment load to a large extent, it does not have formality in the writing courses, and instructors use PA activities just as brain storming ideas not as an assessment activity that may help them in the future. Learners are not able to find the correct steps of using PA unless by the guidance of their teachers.

\section{Conclusions:}

In the light of the findings of the study, it can be concluded that PA is used in the Essay writing classes at the English Departments of Salahaddin University-Erbil; however, the instructors do not follow the steps that can be considered as the procedures of implementing PA because they do not use PA as a kind of assessment, but as a technique to develop the style of learning in their classes. Moreover, PA does not have a formal position in the assessment process of the courses.

Furthermore, it is inferred that students face difficulties while implementing PA such as lack of confidence, using their mother tongue and poor level of language. 


\section{Recommendations:}

The researchers believe that PA is the most vigorous type of alternative assessment that can be utilized in the language classes, especially in writing classes. It develops the critical thinking of the learners and allows them to criticize the works of their peers as well as their personal works intellectually. For this reason, the researchers highly recommend the English Department staffs to apply PA as a kind of their formative assessments formally and provide their students with suitable strategies for implementing PA according to the system of the colleges.

Moreover, teachers are recommended to pay more attention to the use of PA in their course books (syllabus). They are suggested to use a book entitled Longman Academic Writing: Series 4-Essays, $5^{\text {th }}$ edition by Alice Oshima \& Ann Hogue as it is specified for writing essays where 'peer-review and self-checking' forms are used for each chapter. These forms help the learners to check what they have done and share it with their partners. The peer-review form is appropriate to be indicated as a rubric for PA. In this book all the procedures of implementing PA are found and many opportunities are given to students to practice PA and to develop their levels of language.

Finally, the researchers recommend the heads of English Departments at Salahaddin University to give a presentation or hold a workshop about using PA for the instructors who teach writing to prepare some appropriate rubrics to be used in PA activities, and setting the procedures of implementing PA according to the educational situations of Salahaddin University. 


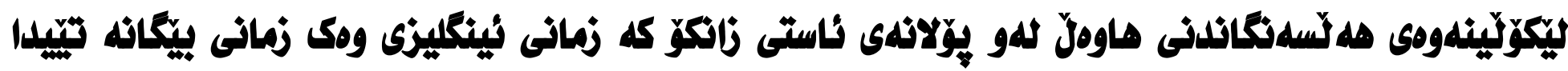 بلهكاريّيت}

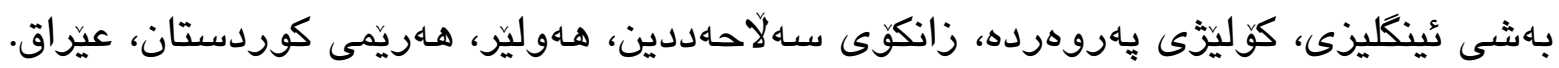
زمينهب حسن رهشيد zeynebhasan92@gmail.com بيمهيلّ

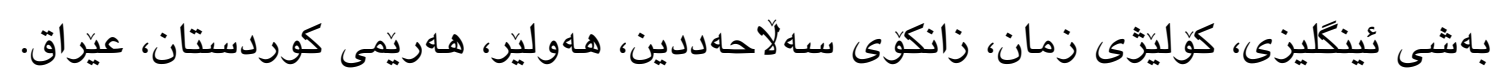
فاتيعه رِّشيد حسن باجهلانى fatimah.hassan@su.edu.krd :يمـايلْ

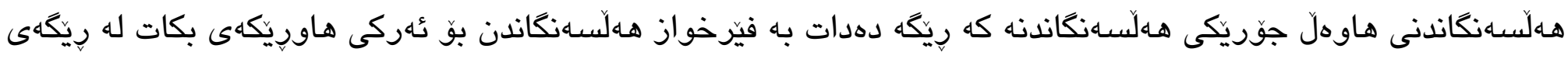

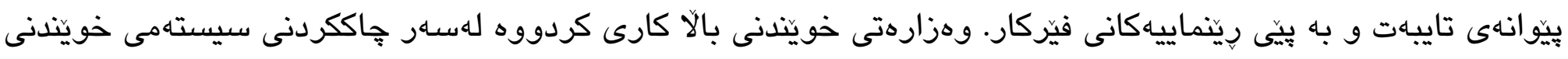

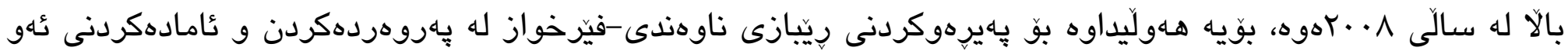

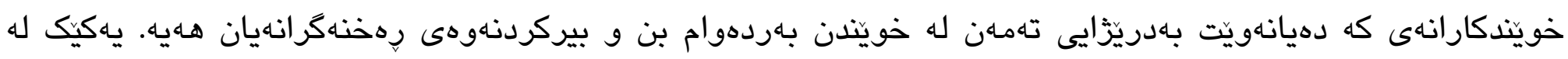

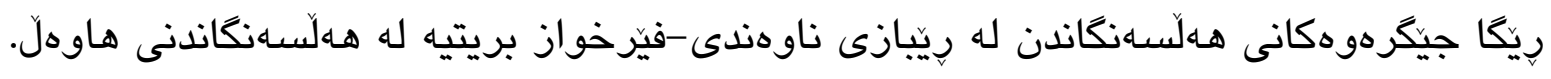

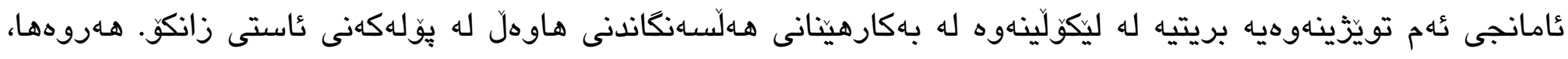

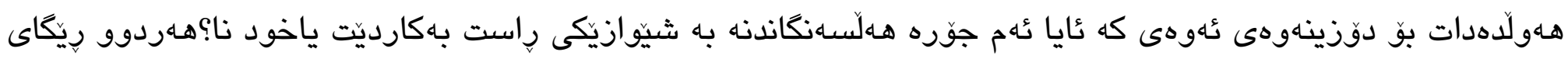

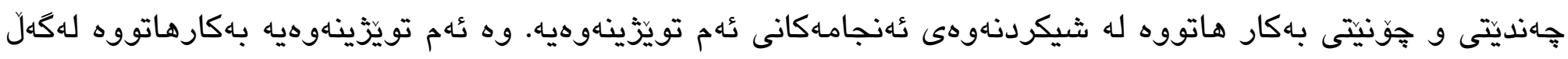

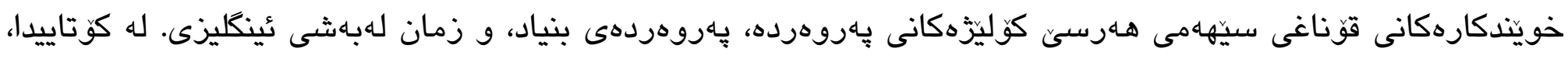

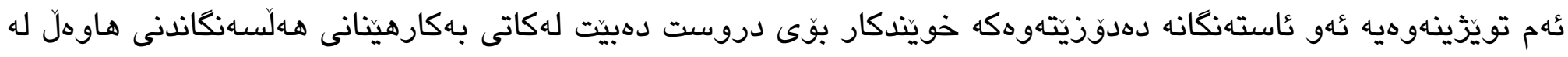

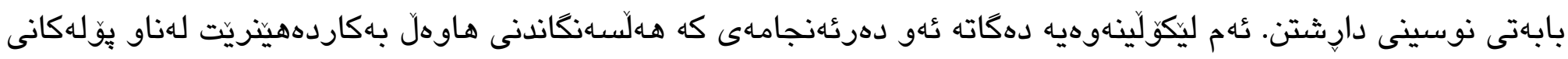

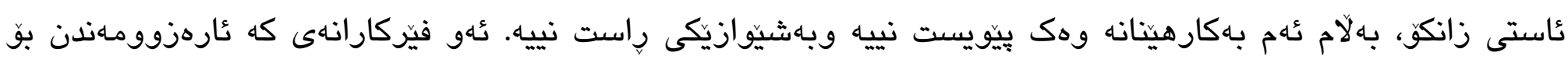

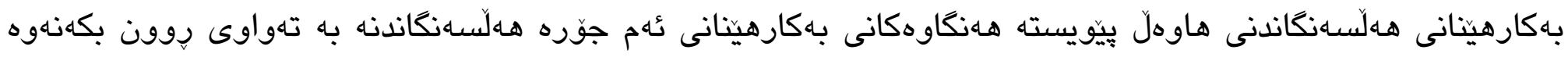
بو خوينّدارهكان.

كليله وشُهكان: هـلّسهنكاندنى هاوهل، فيّربوون بهشيّوهى ناوهندنى فيّرخواز، جِاوديّرى. 


\section{Bibliography:}

Al Bajalani, F. R. \& Kiani, M., 2018. The Implementation of the Learner-Centered Instruction at Knowledge University. Journal of Raparin University, 4(15), pp. 43-58.

Best, J. W. \& Kahn, J. V., 2006. RESEARCH IN EDUCATION. 10th ed. Boston: Pearson.

Brace, I., 2004. QUESTIONNAIRE DESIGN HOW TO PLAN, STRUCTURE AND WRITE SURVEY MATERIAL FOR EFFECTIVE MARKET RESEARCH. London: Kogan Page.

Brown, H. D., 2001. Teaching by Priciples An Interactive Approach to Language Pedagogy. 2nd ed. New York: Longman.

Brown, H. D. \& Abeywickrama, P., 2010. Language Assessment Priciples and Classroom Practices. 2nd ed. NewYork: Pearson.

Creswell, J. W., 2014. Research design : qualitative, quantitative, and mixed methods approaches. 4th ed. London: SAGE.

Falchikov, N. \& Golfinch, J., 2000. Student Peer Assessment in Higher Education: A Meta-Analysis Comparing Peer and Teacher Marks. Review of Educational Research, 70(3), pp. 287-322.

https://doi.org/10.3102\%2F00346543070003287

Gillham, B., 2000. Case Study Research Methods. 1 ed. London: Continuum.

Johnson, R. B. \& Christensen, L., 2014. Educational research: Quantitative, qualitative, and mixed approaches. 5th ed. London: SAGE.

Koc, C., 2011. The Views of Prospective Class Teachers about Peer Assessment in Teaching Practice. Educational Sciences: Theory \& Practice, 11(4), pp. 1979-1989.

http://www.edam.com.tr/estp.asp

Landry, A., Jacobs, S. \& Newton, G., 2015. Effective Use of Peer Assessment in a Graduate Level Writing Assignment: A Case Study. International Journal of Higher Education, 4(1), pp. 38,51. http://www.sciedupress.com/ijhe 
Lladó, A. P. et al., 2013. Student Perceptions of Peer Assesment: An Interdisciplinary Study. Assessment \& Evaluation in Higher Education, Volume 9, pp. 1-29.

https://doi.org/10.1080/02602938.2013.860077

Mackey, A. \& Gass, S. M., 2005. Second Language Research Methodology and Design. UK: Lawrence Erlbarum Associates.

Mutwarasibo, F., 2018. University students' attitudes towards peer assessment and reactions to peer feedback on group writing. Rwanda Journal, 1(2305-2678), pp. 32-48.

http://dx.doi.org/10.4314/rj.v1i1.4A

Race, P., 2001. A Briefing on Self, Peer and Group Assessment. LTSN Generic Centre, 1(9), pp. 1-31. http://www.styluspub.com.

Sluijsmans, H. D. M., 2002. Student involvement in assessment The training of peer assessment skills. Maastricht: Omslag:Open Universiteit Nederland.

Topping, K. J., 2019. Using Peer Assessment to Inspire Reflection and Learning. London: Routledge. 


\section{Appendices 1}

The Questionnaire

\begin{tabular}{|c|c|c|c|}
\hline ITEMS & Always & Sometimes & Never \\
\hline 1. We do peer-assessment in pairs. & & & \\
\hline 2. Our course is learner-centered. & & & \\
\hline $\begin{array}{l}\text { 3. We have the necessary skills to participate in a } \\
\text { peer-assessment process. }\end{array}$ & & & \\
\hline 4. We can help others to improve their work. & & & \\
\hline $\begin{array}{l}\text { 5. Our teacher clearly explains the procedure for } \\
\text { effective peer-assessment. }\end{array}$ & & & \\
\hline $\begin{array}{l}\text { 6. We are given some strategies about how to do } \\
\text { peer-assessment, before we start the process. }\end{array}$ & & & \\
\hline $\begin{array}{l}\text { 7. We are provided with clear (general/specific) } \\
\text { criteria, to be used in the peer-assessment } \\
\text { process. }\end{array}$ & & & \\
\hline $\begin{array}{l}\text { 8. Teacher observes all the process while we are } \\
\text { peer-assessing our works. }\end{array}$ & & & \\
\hline $\begin{array}{l}\text { 9. We take the peer-assessment activities } \\
\text { seriously and it has a formal status in the } \\
\text { course. }\end{array}$ & & & \\
\hline $\begin{array}{l}\text { 10. We are asked about what we have learnt from } \\
\text { the peer-assessing activity. }\end{array}$ & & & \\
\hline $\begin{array}{l}\text { 11. Our teacher makes the tools and instruments } \\
\text { available for us to perform effective peer- } \\
\text { assessment. }\end{array}$ & & & \\
\hline $\begin{array}{l}\text { 12. Peer-assessment means a lot of responsibility } \\
\text { for us. }\end{array}$ & & & \\
\hline $\begin{array}{l}\text { 13. Peer-assessment is more than only a "ticking } \\
\text { and crossing" exercise. We need to write } \\
\text { comments on the work we assessed. }\end{array}$ & & & \\
\hline $\begin{array}{l}\text { 14. We use our mother language in writing } \\
\text { comments. }\end{array}$ & & & \\
\hline $\begin{array}{l}\text { 15. We lack self-confidence while writing } \\
\text { comments for our peers'. }\end{array}$ & & & \\
\hline
\end{tabular}




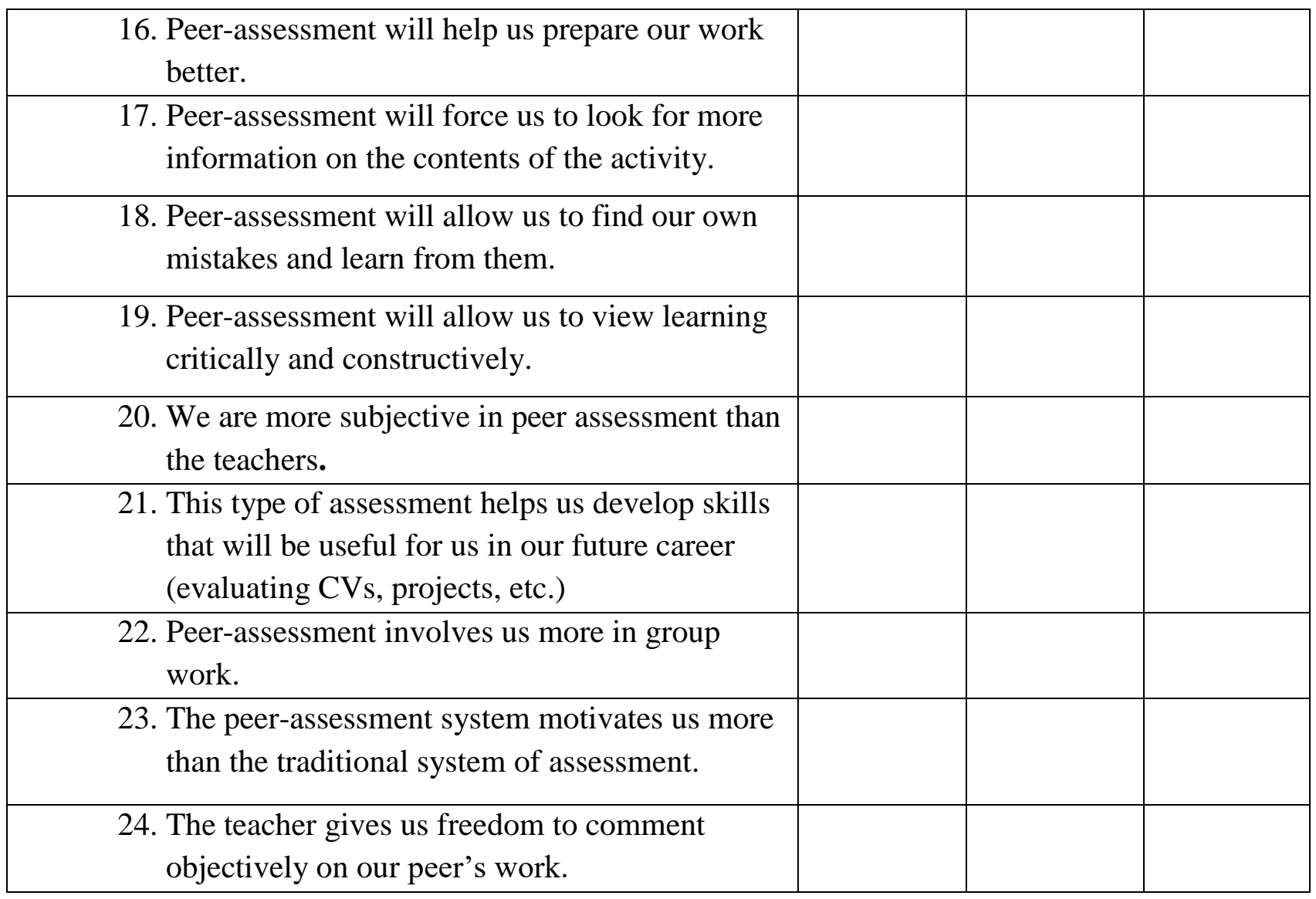




\section{Appendices 2 \\ The Observation Checklist}

Observer's name:

Date of Observation:
College:

Time:

\begin{tabular}{|c|c|c|c|}
\hline Category & ITEMS & Yes & No \\
\hline \multirow{4}{*}{ 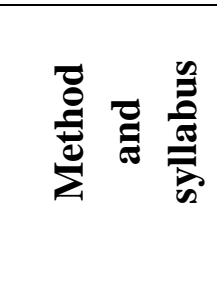 } & 1. The course is learner-centered. & & \\
\hline & 2. The course is teacher-centered. & & \\
\hline & 3. Students are working in pairs. & & \\
\hline & $\begin{array}{l}\text { 4. Peer assessment has a formal status in the course } \\
\text { book (course syllabus). }\end{array}$ & & \\
\hline \multirow{8}{*}{ 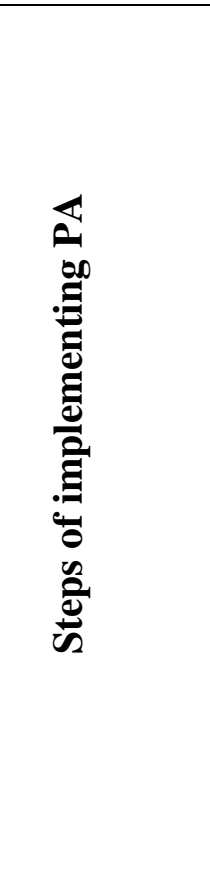 } & $\begin{array}{l}\text { 5. Teachers clearly explain the procedure for } \\
\text { effective peer-assessment. }\end{array}$ & & \\
\hline & $\begin{array}{l}\text { 6. Teachers give some strategies about how to do } \\
\text { peer-assessment before students start the process. }\end{array}$ & & \\
\hline & $\begin{array}{l}\text { 7. Teachers provide students with clear criteria, to } \\
\text { be used in the peer-assessment process (rubric). }\end{array}$ & & \\
\hline & $\begin{array}{l}\text { 8. Teachers monitor the whole process while } \\
\text { students are peer-assessing their works. }\end{array}$ & & \\
\hline & $\begin{array}{l}\text { 9. Students use only "tick and cross" exercise in } \\
\text { Peer-assessment. }\end{array}$ & & \\
\hline & $\begin{array}{l}\text { 10. Students write comments on the work they } \\
\text { assess. }\end{array}$ & & \\
\hline & 11. Students help each other to improve their work. & & \\
\hline & $\begin{array}{l}\text { 12. Teachers ask students about what they have } \\
\text { learnt from the peer-assessing activity. }\end{array}$ & & \\
\hline \multirow{3}{*}{ 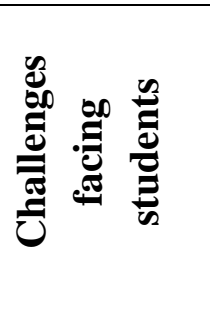 } & $\begin{array}{l}\text { 13. Students find peer-assessment activities as time } \\
\text { consuming and hard to perform. }\end{array}$ & & \\
\hline & $\begin{array}{l}\text { 14. Students use their mother language in writing } \\
\text { comments. }\end{array}$ & & \\
\hline & $\begin{array}{l}\text { 15. Students lack self-confidence while writing } \\
\text { comments for their peers. }\end{array}$ & & \\
\hline$\frac{n}{0}$ & & & \\
\hline
\end{tabular}

